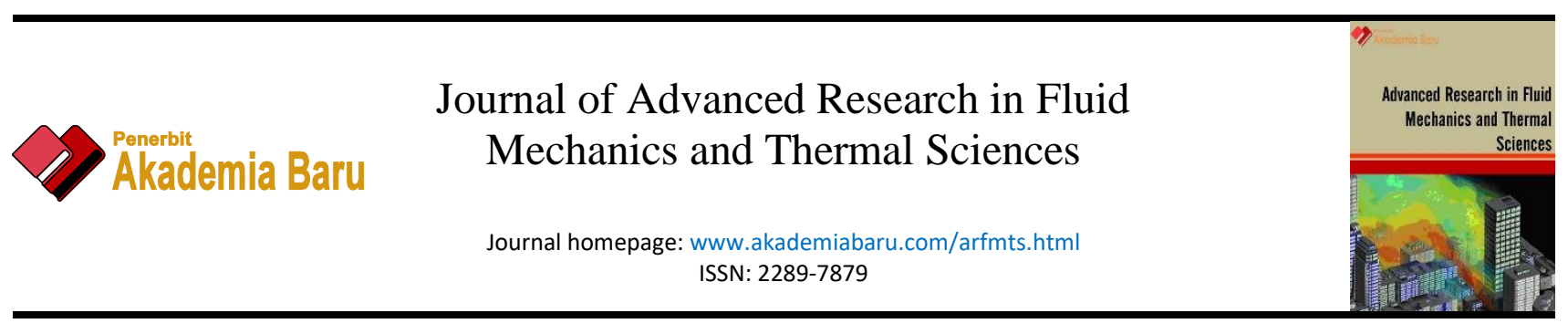

\title{
The Potential of Solar Energy for Domestic and Commercial Buildings in Malaysia
}

\author{
Chee Kar Wei ${ }^{1}$, Abdul Yamin Saad ${ }^{1, *}$ \\ 1 School of Mechanical Engineering,Universiti Sains Malaysia,14300 Nibong Tebal, Penang,Malaysia
}

\begin{tabular}{|c|c|}
\hline ARTICLE INFO & ABSTRACT \\
\hline $\begin{array}{l}\text { Article history: } \\
\text { Received } 15 \text { April } 2020 \\
\text { Received in revised form } 1 \text { August } 2020 \\
\text { Accepted } 9 \text { August } 2020 \\
\text { Available online } 25 \text { September } 2020\end{array}$ & $\begin{array}{l}\text { The rise in electricity consumption can affect global warming and climate change. } \\
\text { Exploitation of solar energy is amongst the most sustainable and relatively cheap } \\
\text { solution in Malaysia. It is imperative to study the potential of its application for } \\
\text { domestic and commercial buildings. In this paper, financial viability of grid-connected } \\
\text { solar photovoltaic (PV) system for domestic and commercial buildings is analysed using } \\
\text { payback period and return on investment (ROI). The payback period and ROI are } \\
\text { determined and compared based on Feed-in Tariff (FiT) and revised Net Energy } \\
\text { Metering (NEM) schemes. Various scenarios and case studies were conducted using } \\
\text { factors such as availability, installation, maintenance, and depreciation. It was found } \\
\text { that domestic consumers i.e. homes with monthly electricity bills of RM } 2500 \text { and } \\
\text { RM5000 had the shortest payback period at } 8.7 \text { years for both schemes. For the } \\
\text { commercial buildings with average bill of RM5003.43 the shortest payback period was } \\
8.2 \text { years for both schemes. The ROI of solar PV system installed for this commercial } \\
\text { building were } 155.03 \% \text { (FiT) and } 203.65 \% \text { (revised NEM). Thus, solar PV system under } \\
\text { FiT and revised NEM schemes would be financially viable for commercial buildings with } \\
\text { monthly electricity bills of RM } 2500 \text { and RM5000. }\end{array}$ \\
\hline
\end{tabular}

Keywords:

Solar energy; photovoltaic; payback period; domestic consumers

Copyright @ 2020 PENERBIT AKADEMIA BARU - All rights reserved

\section{Introduction}

Apart from the fact that solar electricity generation represents a cleaner power source compared to electricity from fossil fuels, with no issues of climate change and global warming, no risks of spike in electricity price, and no threats to our public health [1], solar photovoltaic (PV) system also offers consumers and businesses the ability to reduce costs of electricity bill and increase profitability as a means of generating long term income.

Nowadays, with the cost of producing solar power that is declining rapidly and efficiency of solar panel that is increasing steadily, it is a sign that the world may be on the verge of a dramatic change in how we power our buildings. The price drop is likely to spur a shift towards renewable power

\footnotetext{
* Corresponding author.

E-mail address: meyamin@usm.my
}

https://doi.org/10.37934/arfmts.75.3.9198 
sources like solar energy and away from fossil fuels like natural gas and coal in the future. By the end of 2016, the levelised cost of energy of solar, for the first time, is lower than coal in terms of $\$$ cent/ $\mathrm{kWh}$ (Figure 1). Not only that, it is found that the price of solar panel per watt has dropped from $\$ 101.05$ to as low as $\$ 0.37$ in late 2017 [2].

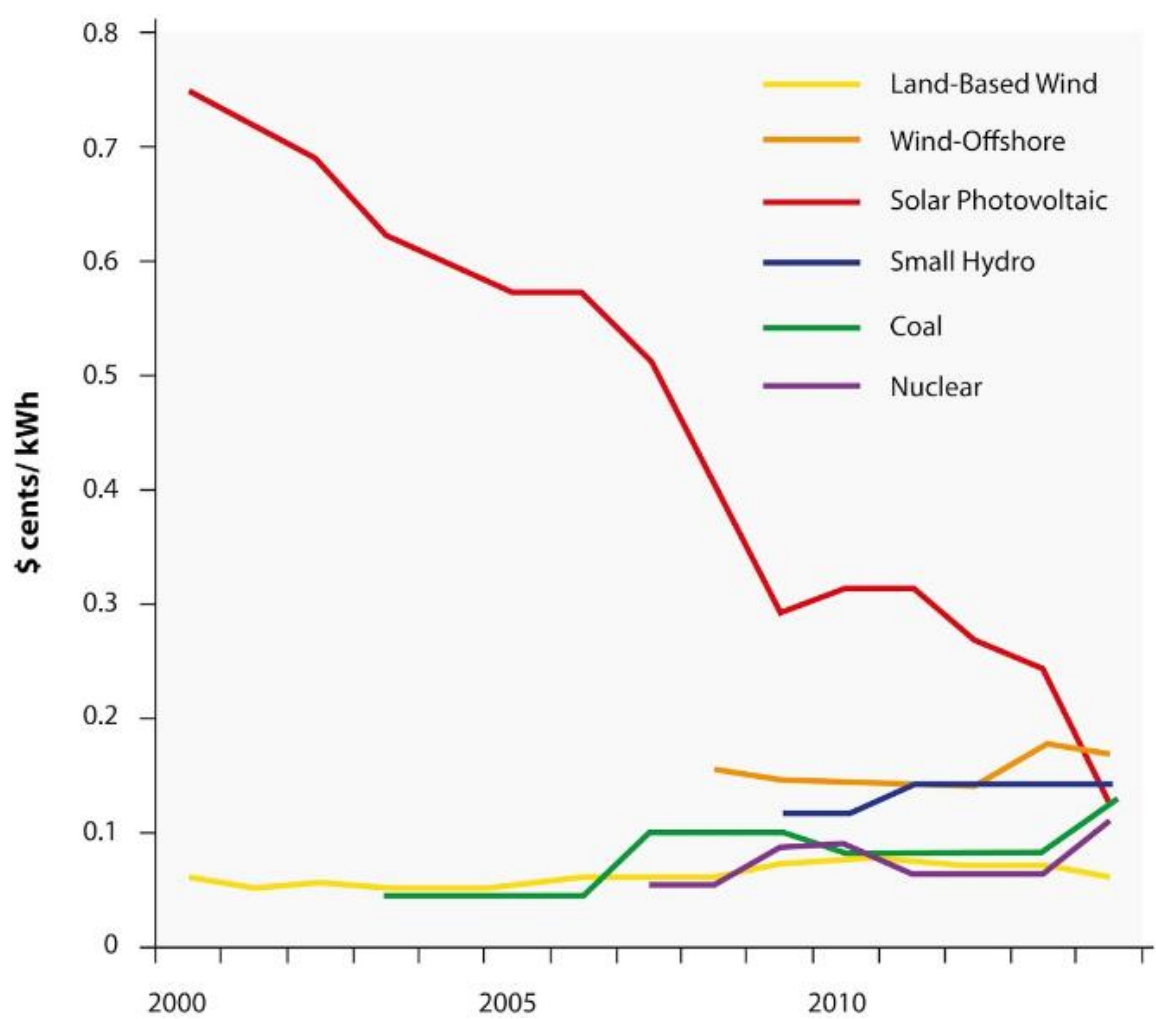

Fig. 1. Levelised Cost of Energy (World Average) by energy type [3]

Next, solar energy as a viable option for consumers and businesses is closely related to the payback period or return of investment (ROI) under the policies of Feed in Tariff (FiT) scheme and Net Energy Metering (NEM) scheme in Malaysia. To encourage the growth of solar energy sector in domestic, commercial, and even industrial consumers, the first introduced policy was Feed in Tariff (FiT) scheme in 2011 where grid-connected solar photovoltaic (PV) generators will be paid in cash for the amount of extra electricity they have generated [4]. According to the study published by Solar Energy Research Institute (SERI) from Universiti Kebangsaan Malaysia, the payback period for vertical photovoltaic facade system on a high rise building in Malaysia is about 12 years while the horizontal façade system is about 6 years for Tariff C1 (Medium Voltage General Commercial Tariff) under FiT scheme [5]. Nevertheless, the application of FiT scheme was closed for registration in the year 2016.

To solve the problem above, Net Energy Metering (NEM) scheme was introduced in Nov 2016 where energy produced from solar PV system installed will be consumed first, and any excess to be exported and sold to the Distribution Licensees (DLs) i.e. TNB /SESB at the prevailing Displaced Cost prescribed by the Energy Commission [5]. Sadly, as of October 2018, the total amount of NEM quota taken up is disappointingly low at only $17 \mathrm{MW}$ (megawatt) or $3 \%$, out of the $500 \mathrm{MW}$ [6]. The reasons for this low uptake are caused by the extremely low rate at which consumer can sell the energy produced by the solar PV system at 31 sen per kWh compared to purchase electricity at about 50 sen per kWh and even worse the excess electricity sold to DLs will be paid in credit rather than cash.

Again, to solve the low uptake of NEM quota, Minister of Energy, Science, Environment, and Climate Change, Yeo Bee Yin announced that starting $1^{\text {st }}$ of Jan 2019, there will be no difference in 
sale and purchase prices for electricity under a revised NEM scheme. This means that the excess electricity generated from solar PV system will be exported back to the grid on a 'one-on-one' offset basis [7].

With the revised NEM scheme announced, the viability of solar PV system will definitely catch the attention of consumers. Therefore, the current study will focus mainly on grid-connected solar PV system without battery storage by comparing the financial viability of solar PV system in both the domestic and commercial buildings based on available electricity consumption profile. By doing so, there will be a guidance to solar power system for consumers before they invest in a photovoltaic system in the future.

\section{Methodology}

The solar payback period and return on investment (ROI) are the major factors that govern the interest of consumers to install solar PV system in their houses. Solar payback period is a calculation that estimates how long it will take for you to "break even" on your solar energy investment [8]. Return on investment (ROI) is a performance measure used to evaluate the returns of an investment or to compare efficiency between different investments. ROI measures the return of an investment relative to the cost of the investment [9].

In this study, the result is separated into Part I and Part II where the steps taken are shown in Figure 2. Financial viability of a various sizes of solar photovoltaic (PV) systems through payback period under different monthly electric bill is shown in Part I. Payback periods and return on investment (ROI) of three buildings under different tariffs are shown in Part II.
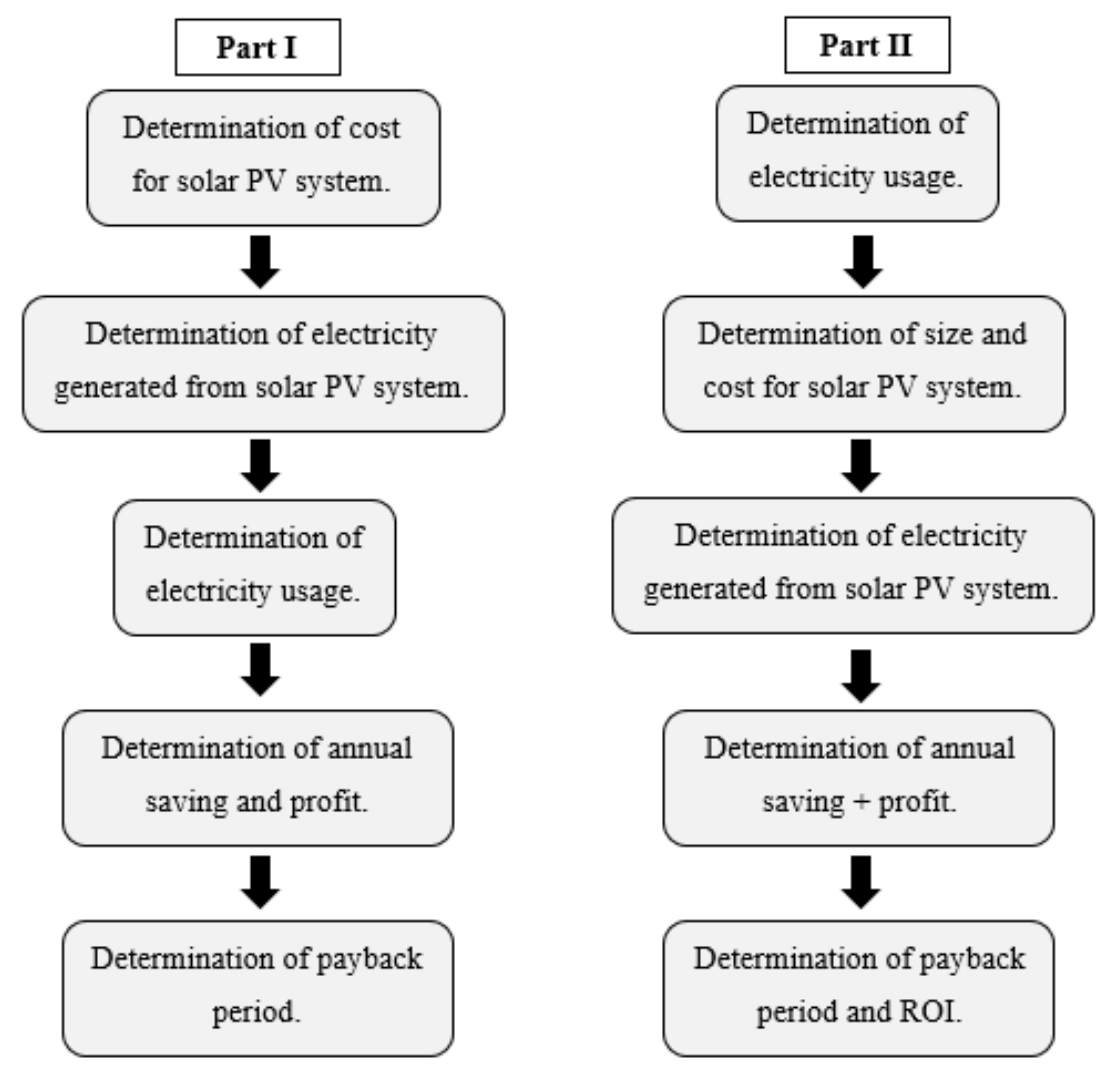

Fig. 2. Steps taken to calculate payback period and return on investment (ROI) 
In Malaysia, it costs around RM10,000 - RM15,000 for each system capacity of $1 \mathrm{kWp}$ [10]. However, it is very difficult to propose an exact amount of money needed for a complete solar PV system. Therefore, the costs estimated for different sizes of solar PV systems with maintenance and operation costs included, are assumed as shown in Table 1 below.

The monthly electricity generated by solar PV system is calculated based on the size of solar PV system and solar irradiation at a particular location. The values of solar irradiation for different locations are obtained directly from Global Solar Atlas. The solar irradiation for Jinjang, Kuala Lumpur is 4.564 hours [11], Kampung Kedah, Perak is 5.09 hours [12] and Nibong Tebal, Penang is 5.121 hours [13]. Assumptions made are location selected for Tariff $A$ is Jinjang, Kuala Lumpur, location selected for Tariff B is Kampung Kedah, Perak and location selected for Tariff C1 is Nibong Tebal, Penang.

The monthly electricity usage for every category of consumer or building is determined by two criteria which are the monthly electric bill and Distribution Licensees (DLs) gazetted tariff i.e. TNB/ SESB. The gazetted tariff used in this study is taken from Tenaga Nasional Berhad (TNB) official website. The monthly electric bills are considered to be constant throughout 21 years for FiT scheme and 25 years for revised NEM scheme.

To calculate the payback period of a solar PV system, cost of solar PV system is first estimated based on Table 1. After that, total saving from the monthly electric bill and total profit after the installation of solar PV system must be determined as well. Two scenarios are involved when calculating annual total saving and annual total profit. First, the annual total profit is zero and only annual total saving is available if there is not any excess electricity generated from solar PV system. Second, there is excess electricity generated from solar PV system where the annual total saving is the exact amount of monthly electric bill for a year and annual total profit is calculated.

Lastly, return on investment (ROI) is calculated based on few assumptions which are shown below

i. 21 years of effective contract period is considered for FiT scheme [4].

ii. 25 years of effective period is considered for revised NEM scheme based on the average lifespan of a solar PV system [14].

iii. Cost of investment is equal to cost of solar PV system.

iv. Annual saving + profit is considered to remain constant throughout the 21 years for FiT scheme and 25 years for revised NEM scheme.

Table 1

Costing of solar PV system

\begin{tabular}{|c|c|c|c|}
\hline No & Item & Price & Remark \\
\hline 1 & Components-Solar panel & RM1.00/ watt & 300 watt solar panel (Alibaba price) \\
\hline 2 & $\begin{array}{l}\text { Components-Solar } \\
\text { mounting system }\end{array}$ & RM0.55/ watt & $\begin{array}{l}\text { Roof mounted solar mounting system. (Alibaba } \\
\text { price) }\end{array}$ \\
\hline 3 & Components-Inverter & RM1932/ kilowatt & $\begin{array}{l}\text { RM } 8500 \text { for a } 4.4 \mathrm{~kW} \text { inverter. (Wholesale Solar } \\
\text { price) }\end{array}$ \\
\hline 4 & $\begin{array}{l}\text { Components-Electric } \\
\text { meter }\end{array}$ & RM1112/ unit & 1 unit is needed for every solar PV system. \\
\hline 5 & Free on board (FOB) & $\begin{array}{l}40 \% \text { of total component's } \\
\text { price }\end{array}$ & $\begin{array}{l}\text { Charges implied on buyer for shipping of } \\
\text { goods. }\end{array}$ \\
\hline 6 & $\begin{array}{l}\text { Operation \& Maintenance } \\
\text { ( } 25 \text { years) }\end{array}$ & $\begin{array}{l}1.5 \% \text { of total component's } \\
\text { price }[15,16]\end{array}$ & Average system lifespan is 25 years (Cost $x 25$ ). \\
\hline 7 & Labor & RM1.50/ watt & - \\
\hline 8 & Miscellaneous & $5 \%$ from total price & $\begin{array}{l}\text { Includes application fee for scheme, insurance, } \\
\text { fee of study and etc. }\end{array}$ \\
\hline
\end{tabular}

*Assuming 1 USD = 4 MYR for the conversion of components' prices.

\subsection{Part I}


Payback periods of solar photovoltaic (PV) system for Feed in Tariff (FiT) scheme and revised Net Energy Metering (NEM) scheme are shown in Part I, at three different locations based on different sizes of system, monthly electric bills and DLs i.e. Tenaga Nasional Berhad (TNB) pricing \& tariffs.
a) Tariff
: A - Domestic Tariff
Location
: Jinjang, Kuala Lumpur
Monthly electric bill : RM200 (low), RM400 (medium), RM600 (high)
b) Tariff
Location
: B - Low Voltage Commercial Tariff
Monthly electric bill
: Kampung Kedah, Parit Buntar
c) Tariff
Location
RM2500 (low). RM5000 (medium), RM7500 (high)
: C1 - Medium Voltage General Commercial Tariff
: Nibong Tebal, Pulau Pinang
Monthly electric bill : RM10,000 (low), RM15,000 (medium), RM20,000 (high)

\subsection{Part II}

Payback period and return on investment (ROI) of solar photovoltaic (PV) system for Feed in Tariff (FiT) scheme and revised Net Energy Metering (NEM) scheme are shown in Part II, at three buildings of different locations under different DLs i.e. TNB pricing \& tariffs which are shown as below
a) Tariff
Location
: A - Domestic Tariff
Building type
: Jinjang, Kuala Lumpur
b) Tariff : B - Low Voltage Commercial Tariff
Location : Kampung Kedah, Perak
Building type : Fuel station
c) Tariff : : 1 - Medium Voltage General Commercial Tariff
Location : Nibong Tebal, Pulau Pinang
Building type : Educational institution

The average usage of electricity are $613.50 \mathrm{kWh}$ for single storey semi-detached house (Tariff A), 9330.17 kWh for fuel station (Tariff B) and $34463.12 \mathrm{kWh}$ for educational institution (Tariff C1).

\section{Results}

\subsection{Part I}

It is also found that as long as the solar PV system generates yearly profit from excess electricity, the payback period will be even shorter compared to the shortest payback period obtained when there is not any excess electricity generated or zero yearly profit under FiT scheme (See Table 2).

Besides that, it is found that the excess electricity generated from solar PV system is redundant under revised NEM scheme assuming that the monthly electricity bills are constant throughout the 25 years solar PV system's lifespan. The reason being is that the excess electricity generated under NEM scheme is paid by DLs to the consumers in terms of credit which is used to deduct the subsequent month's electricity bill. However, the credit is not required as the solar PV system is already generating excess electricity every month after covering the consumers' monthly electricity usage plus the credit is allowed to roll over for a maximum of 24 months only. As a result, the payback 
period for revised NEM scheme is found to be longer as the system's size increases with increasing cost after the point where excess electricity is generated.

\section{Table 2}

Results (Part I)

\begin{tabular}{llll}
\hline Tariff & $\begin{array}{l}\text { Monthly electricity } \\
\text { usage }\end{array}$ & $\begin{array}{l}\text { Monthly Electric } \\
\text { Bill }\end{array}$ & $\begin{array}{l}\text { Payback Period } \\
\text { (year) }\end{array}$ \\
\hline A- Domestic & Low & RM200 & 11.0 \\
& Medium & RM400 & 9.8 \\
& High & RM600 & 9.2 \\
B- Low Voltage Commercial & Low & RM2500 & 8.7 \\
& Medium & RM5000 & 8.7 \\
& High & RM7500 & 9.7 \\
C1- Medium Voltage General & Low & RM10000 & 12.0 \\
Commercial & Medium & RM15000 & 12.1 \\
& High & RM20000 & 12.1 \\
\hline
\end{tabular}

*Applicable to both FiT and revised NEM scheme without any excess electricity generated.

\subsection{Part II}

Table 3 shows the results for Part II

\section{Table 3}

Results (Part II)

\begin{tabular}{|c|c|c|c|c|}
\hline Tariff & $\begin{array}{l}\text { Size of solar PV } \\
\text { system }\end{array}$ & $\begin{array}{l}\text { Cost of solar PV } \\
\text { system }\end{array}$ & $\begin{array}{l}\text { Payback Period } \\
\text { (yr) }\end{array}$ & ROI (\%) \\
\hline $\begin{array}{l}\text { A - Single storey semi- } \\
\text { detached house }\end{array}$ & $4.5 \mathrm{kWp}$ & RM38,363.10 & $\begin{array}{l}12.4 \text { (FiT) } \\
13.1 \text { (NEM) }\end{array}$ & $\begin{array}{l}68.77 \text { (FiT) } \\
91.53 \text { (NEM) } \\
\text { *as shown in Figure } 3\end{array}$ \\
\hline B - Fuel station & $61.1 \mathrm{kWp}$ & RM494,818.20 & $\begin{array}{l}8.2 \text { (FiT) } \\
8.2 \text { (NEM) }\end{array}$ & $\begin{array}{l}155.03 \text { (FiT) } \\
203.65 \text { (NEM) } \\
\text { *as shown in Figure } 4\end{array}$ \\
\hline $\begin{array}{l}\text { C1 - Educational } \\
\text { institution }\end{array}$ & $224.3 \mathrm{kWp}$ & RM1,810,957.20 & $\begin{array}{l}12.1 \text { (FiT) } \\
12.1 \text { (NEM) }\end{array}$ & $\begin{array}{l}76.41 \text { (FiT) } \\
107.10 \text { (NEM) } \\
\text { *as shown in Figure } 5\end{array}$ \\
\hline
\end{tabular}

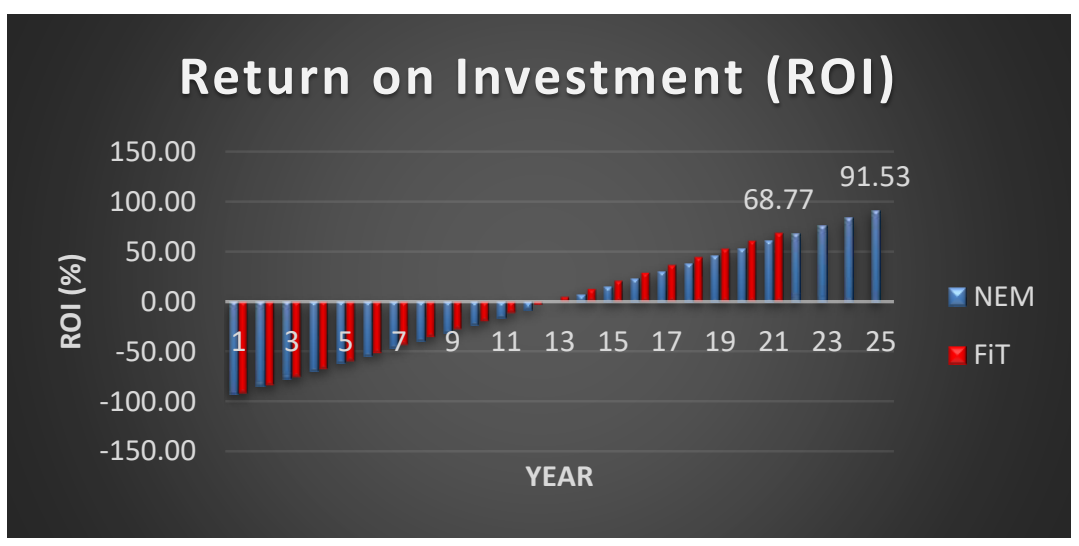

Fig. 3. Graph on return of investment (ROI) for Tariff A 


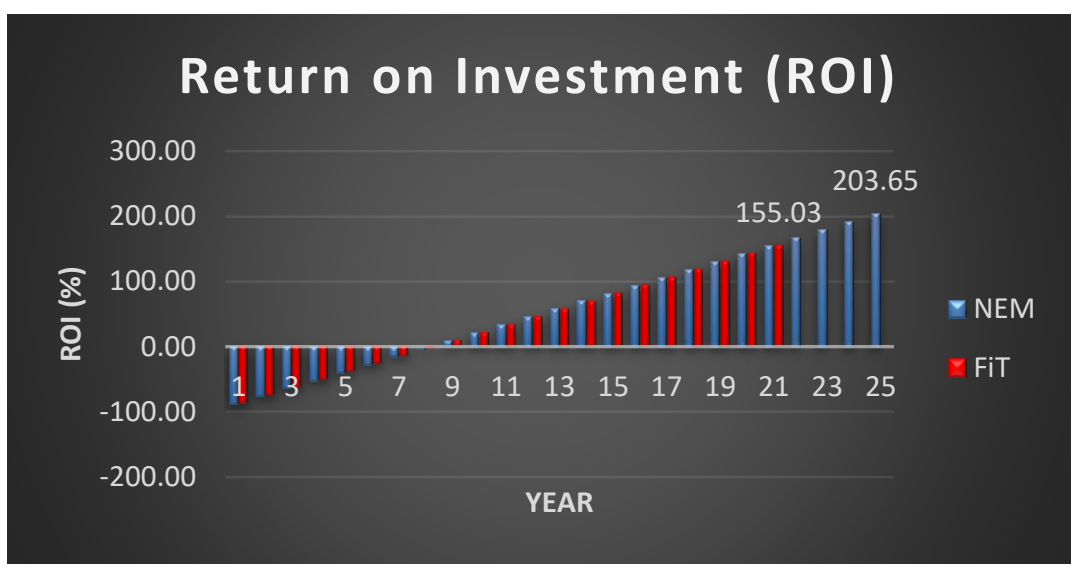

Fig. 4. Graph on return of investment (ROI) for Tariff B

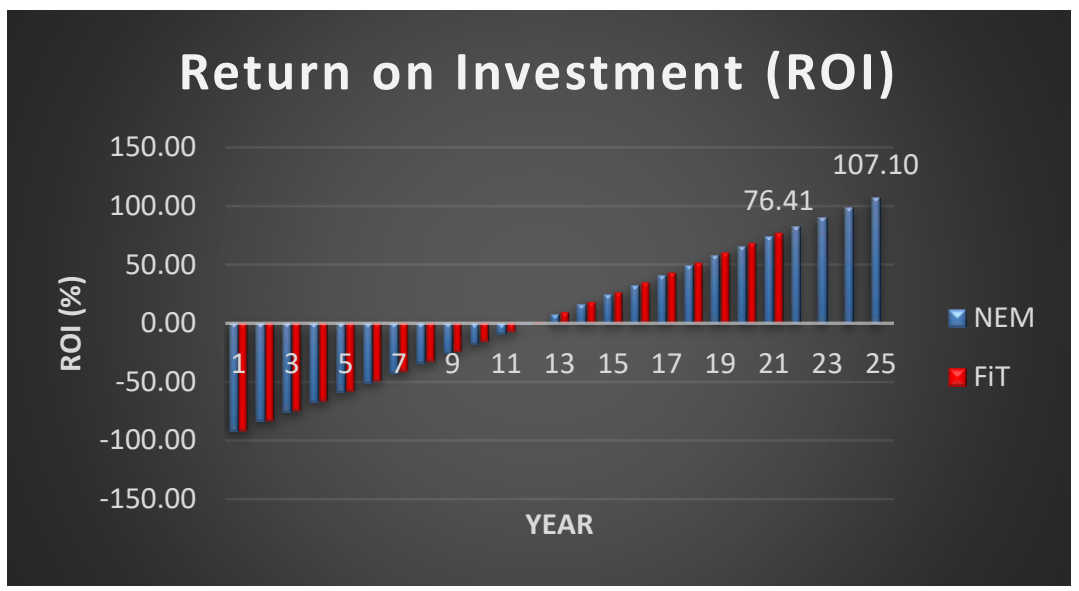

Fig. 5. Graph on return of investment (ROI) for Tariff C1

\section{Conclusions}

In this paper, the financial viability of solar photovoltaic (PV) system has been investigated. In Part I, it is found that for solar PV system without excess electricity generated, low and medium electricity usage consumers under Tariff B - Low Voltage Commercial Tariff have the shortest payback period - 8.7 years with optimum sizing of solar PV system. In Part II, the shortest payback period is found to be 8.2 years when solar system is installed in a fuel station under Tariff B where the ROI is as high as $155.03 \%$ (FiT scheme) and $203.65 \%$ (revised NEM scheme).

\section{Acknowledgement}

The authors would like to record sincere appreciations to those involved in this research including, but not limited to, Petronas Service Station Kampung Kedah, owners of a house in Gelugor and Pusat Pengajian Kejuruteraan Mekanik. This research was funded by a BRIDGING grant from Universiti Sains Malaysia (304.PMEKANIK.6316449).

\section{References}

[1] Backgrounder, Clean Energy. "How Solar Energy Works." 12 2004." Union of Concerned Scientists 16 (2005).

[2] Shahan, Z. "Solar Panel Prices Continue Falling Quicker Than Expected." Clean Technica, accessed May 23 (2018): 2018.

[3] Bleich, Katherine, and Rafael Dantas Guimaraes. "Renewable infrastructure investment handbook: A guide for institutional investors." In World Economic Forum, Geneva. 2016.

[4] "Oveview of the FiT System in Malaysia." Sustainable Energy Development Authority Malaysia. 
[5] Ghazali, A., E. Salleha, C. H. Limb, K. Sopianc, and S. Matd. "Economic Evaluation of Vertical Photovoltaic System on High-rise Building in Malaysia." Journal of Advanced Research in Business and Management Studies 3, no. 1 (2016): 123-138.

[6] "Overview of NEM." Sustainable Energy Development Authority Malaysia.

[7] M. Carvalho, H. Sivanandam and R. Rahim. "From Jan 1, solar power users to enjoy cheaper electricity bills." The Star Online (2018).

[8] Malaysia Investment Development Authority (MIDA). "Beginning 2019, no price difference between solar generation and consumption tariff." 2018.

[9] V. Aggarwal. "How to calculate solar panel payback period (ROI)." EnergySage (2018).

[10] "What is Return on Investment (ROI)?" Corporate Finance Institute.

[11] Choong, M. Y. "Harnessing rooftops to generate solar power." The Star (2012).

[12] "Global Solar Atlas - Jinjang, Kuala Lumpur." 2016.

[13] "Global Solar Atlas - Parit Buntar, Perak." 2016.

[14] "Global Solar Atlas - Nibong Tebal, Pulau Pinang." 2016.

[15] V. Aggarwal. "Are Solar Panels a Sustainable Product?" Mother Earth News (2016).

[16] "What Are The Operational Costs Of A Solar Panel System?" Power From Sunlight (2017). 